\title{
Morphological Studies on the Epididymal Duct of the One-Humped Camel (Camelus dromedaries)
}

\author{
Ahmed E. Zayed ${ }^{1,2}$, Khaled Aly ${ }^{1,3^{*}}$, Ismail A. Ibrahim ${ }^{1}$, Fatma M. Abd El-Maksoud ${ }^{1}$ \\ ${ }^{1}$ Department of Anatomy \& Histology, Faculty of Veterinary Medicine, Assiut University, Assiut, Egypt \\ ${ }^{2}$ Department of Medical Biology, Deanship of Preparatory Year, Jazan University, Jazan, KSA \\ ${ }^{3}$ Department of Medical Laboratories, Faculty of Community in El-Namas City, \\ King Khaled University, Abha, KSA \\ Email: elzuhry@yahoo.com, khaledali69@hotmail.com, Ismail2012@yahoo.com, fatmamaksoud84@yahoo.com
}

Received May 22, 2012; revised July 19, 2012; accepted October 11, 2012

\begin{abstract}
The present work was carried out on 20 epididymes of sexually mature one humped camel to elucidate the gross anatomical, scanning electron microscopical and light microscopical features of the epididymal duct. Anatomically, the epididymal duct of camel consists of three parts i.e. head, body and tail. Histomorphologically, the epididymal duct is subdivided into initial, middle and terminal segments, of which the middle segment is further subdivided into proximal, intermediate and distal parts. The epithelium lining the epididymal duct is ciliated pseudostratified columnar comprising mainly five cell types, namely principal, basal, apical, dark and halo cells. It displays numerous intraepithelial glands in the middle segment. In general, there is a gradual increase in the total diameter and decrease in the epithelial height of the epididymal duct from the initial to the terminal segments; that may, mechanically, facilities passage of the sperms toward the terminal segment. The lamina propria of the epididymal duct contains a layer of interlacing elastic fibers which may allow adequate elasticity of the duct that could help in its expansion. Moreover it is surrounded by numerous layers of circularly and obliquely arranged smooth muscle fibers which always increase in thickness toward the terminal segment.
\end{abstract}

Keywords: Epididymal Duct; Camel; Morphology

\section{Introduction}

The camel is an important livestock species uniquely adapted to hot and arid environments. The primary uses of camels were for the transport of people in desert and semi desert areas [1]. Nowadays a new role was created for the camel as milk, meat, wool, hair and hides production [2]. This drawn attention to the need for efficient reproduction in this species [3]. Compared to other species, the fertilization rate and reproductive capacity of the camel is remarkably low when compared withthat of other domestic mammals $[1,4]$. The epididymis is a dynamic organ that controls not only the maturation and fertility of spermatozoa but also acts as a storage reservoir for spermatozoa [5]. The epididymis is a long highly convoluted duct that is anatomically divided into head, body and tail [6]. However, histologically it is subdivided into initial, middle and terminal segments, and the middle segment is further subdivided into proximal, intermediate and distal parts [7]. The current study aims to elucidate the morphometrical and morphological characteristics of the epididymal duct of

"Corresponding author. the camel in Upper Egypt (Assiut governorate).

\section{Materials and Methods}

The present work was carried out on 20 epididymes collected from mature clinically healthy camels (Camelus dromedarius). The materials were collected from $\mathrm{Ba}-$ niadie slaughter house in Assiut governorate. The materials were then preserved in $10 \%$ formalin and kept for further description.

\subsection{For Scanning Electron Microscopy}

Small pieces were taken from the three segments of the epididymal duct namely; initial, middle and terminal segments, fixed in mixture of paraformaldehyde solution $(2.5 \%)$ and gluteraldehyde solution $(2.5 \%)$ in phosphate buffer ( $\mathrm{pH} 7.3$ ) for 24 hours. The samples were washed in $0.1 \mathrm{M}$ phosphate buffer, dehydrated in graded ethanol, critical point-dried in liquid carbon dioxide, and then coated with gold palladius in sputtering device. The samples were then examined and photographed using JSM-5400LV Scanning electron microscope operated at 
$20 \mathrm{KV}$ in the EM center of Assiut University.

\subsection{For Light Microscopy}

The epididymal duct (immediately obtained after slaughtering) were divided into segments according to [7] as shown in (Figure 1). Small pieces were taken from the different segments, fixed in two kinds of fixatives namely, Bouin's solution [8] and 10\% of neutral buffered formalin. After proper fixation, the specimens were dehydrated in graded ethanol, cleared in xylene, embedded in paraplast and sectioned at $3-5 \mu \mathrm{m}$ thick sections. Sections were stained with Haematoxylin and Eosin staining [9] for demonstration of the general histological structure of the examined epididymis; PAS reaction [10] for demonstration of neutral mucopolysaccharides; Alcian blue $8 \mathrm{G} \mathrm{X}$ $(\mathrm{pH} 2.5)$ and $(\mathrm{pH} 1.0)$ after [11] for detection of acidic mucopoly saccharides; Crossmon's Trichrome [12] for detection of muscles and collagenous fibers and Weigert's resorcinfuchsin [13] for detection of elastic fibers.

\subsection{For Epon-Araldite Embedding}

Small tissue blocks were taken from initial, middle and terminal segments of the epididymalduct fixed in paraformaldehyde-gluteraraldehyde solution in phosphate buffer [14]. Specimens were post fixed in $1 \%$ osmium tetraoxide for one hour, washed in $0.1 \mathrm{M}$ phosphate buffer
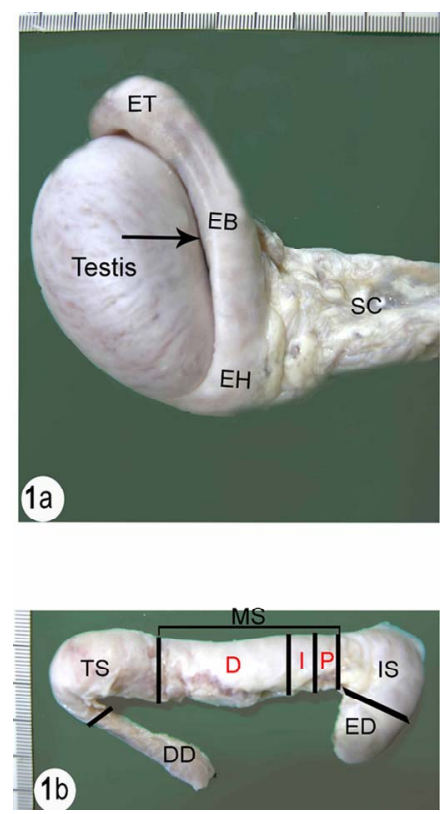

(a) SC (Spermatic cord), EH (Epididymal head), EB (Epididymal body), ET (Epididymal tail). Notice the Testicular bursa (arrow) between the body of the epididymis and the lateral surface of the testis. (b) ED (Efferent ductules), IS (Initial segment), MS (Middle segment), P (Proximal part), I (Intermediate part), D (Distal part), TS (Terminal segment), DD (Ductus deference).

Figure 1. (a) Right testis and epididymis of the camel with a part of the spermatic cord; (b) Dissected right epididymis of the camel with part of ductus deference.
$(7.3 \mathrm{pH})$, then dehydrated in graded ethanol and embedded in epon-araldite mixture [15]. Semithin sections (1 $\mu \mathrm{m})$ were cut, stained with toluidine blue [16]. All sections were examined with light microscope and photographed.

\section{Results}

\subsection{Gross Anatomical Features}

The epididymis consists of a highly convoluted duct which is tightly packed in a thick tunica albuginea. The tunica albuginea covering the epididymis is also covered by the visceral layer of the tunica vaginalis which become continuous with the parietal layer along the length of the epididymis. Anatomically the epididymal duct is composed of three distinct parts: the head, body and tail. The epididymal duct faces laterally along the dorsal border of the testis with the head curving around the cranial pole of the testis. It is attached to the head extremity of the testis by a fibrous band. The body of the epididymal duct is a thick flattened part attached to the dorsal border of the testis and forms a sinus that opens laterally. The tail is a small part attached to the tail extremity of the testis by the proper ligament of the testis and attached to the tunica vaginalis by the ligament of the tail of the epididymis. The epididymal duct is difficult to be visualized through the tunica albuginea particularly in the head and the body of the epididymis (Figure 1).

\subsection{Scanning Electron Microscopy}

In cut sections, the epididymal duct is lined by long pseudostratified columnar epithelium arranged in the form of packed wheat stems (Figure 2). The epithelium in the middle and terminal segments shows variably sized vacuoles (Figures 3 and $\mathbf{4}$ ). The luminal surface of these cells is ciliated. Sometimes, numerous bleb-like

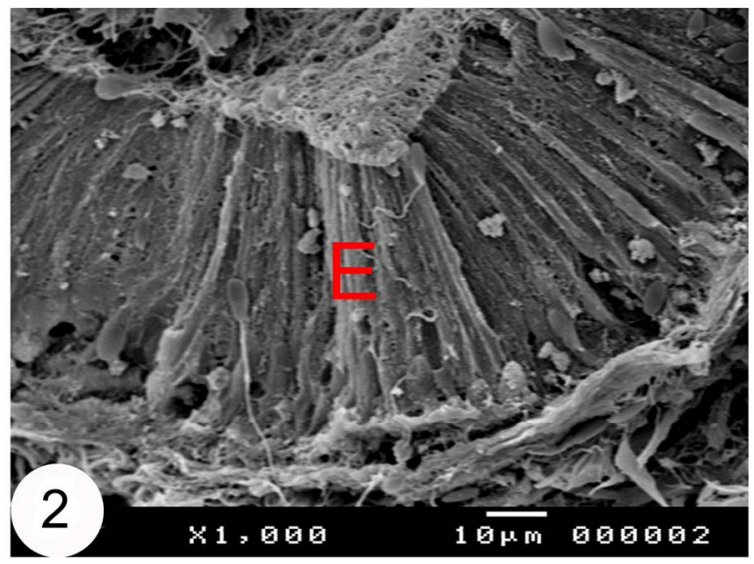

Figure 2. Scanning electron micrographs of the initial segments of the camel epididymis. The epididymal epithelium $(E)$ is arranged in the form of wheat stuffs. 


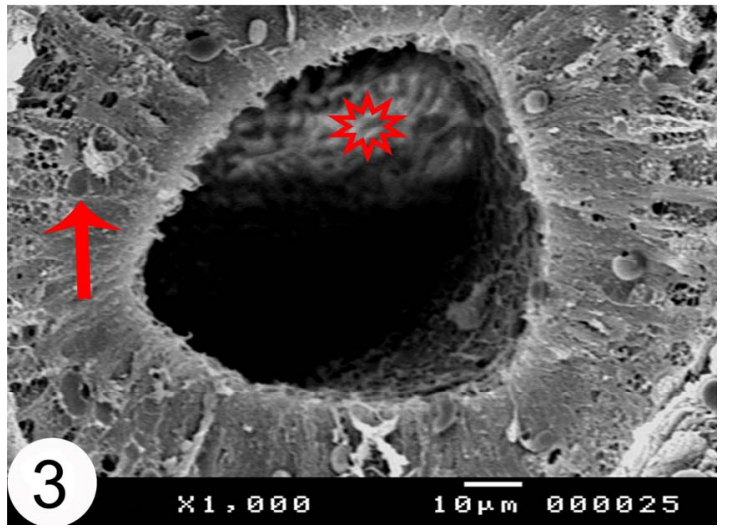

Figure 3. Scanning electron micrographs of the middle segments of the camel epididymis. The lumen of the middle segment contains collection of sperms (asterisk). Notice the presence of the vacuoles (arrow) in the epithelium.

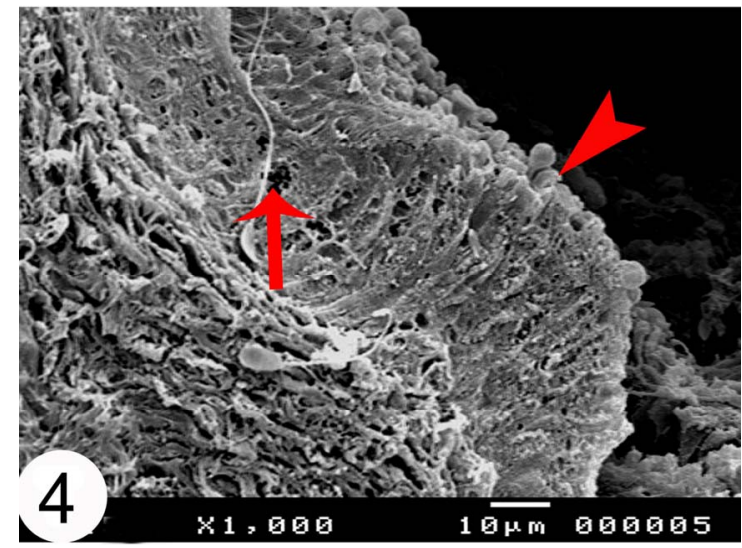

Figure 4. Scanning electron micrographs of the terminal segments of the camel epididymis. Notice the presence of the vacuoles (arrow) in the epithelium. Apperance of apical bleb like protrusions in the terminal segment (arrow head).

protrusions and rounded secretory vesiclesare demonstrated in between and covering the stereocilia. The lumen of the epididymal duct shows collections of sperms in different segments. These collections are mainly seen in the middle segment (Figure 3), however sometimes, they are seen sticking to the luminal surface of the epithelium particularly between the stereocilia (Figure 5). In the terminal segment and at low magnifications, the epididymal duct shows the widest lumen and surrounded by a thickercircularly arranged smooth muscle fibers (Figure 6). Scanning electron microscopy of the camel spermatozoa demonstrated healthy normally looking spermatozoa (Figure 7) but sometimes they are smaller in size and more or less abnormally looking.

\subsection{Light Microscopy}

The epididymal duct of the camel is divided into initial, middle and terminal segments. In addition, the middle

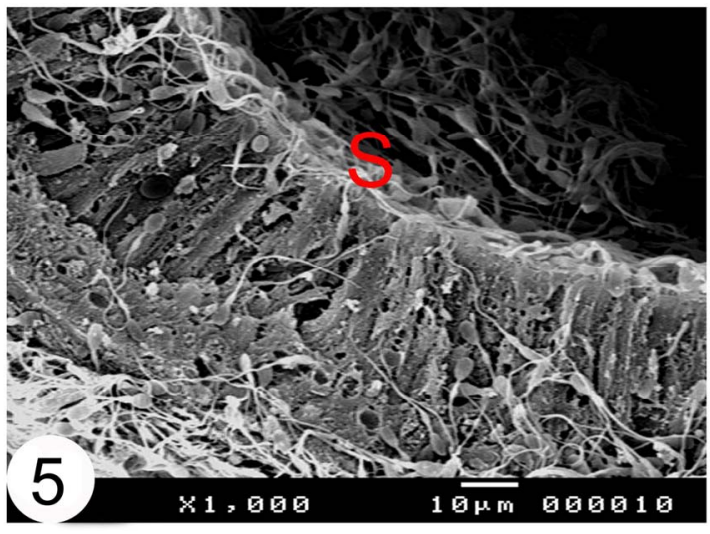

Figure 5. Scanning electron micrographs of the terminal segment of the camel epididymal duct. Notice that the sperms (S) are sticking to the stereocilia of the epididymal epithelium.

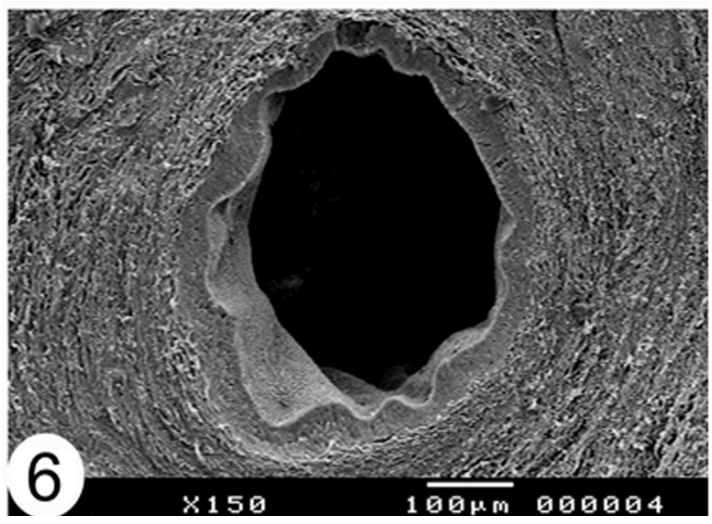

Figure 6. Scanning electron micrographs showing cut sections of the terminal segment of the camel epididymal duct. The lumen of the epididymal duct is the wide.

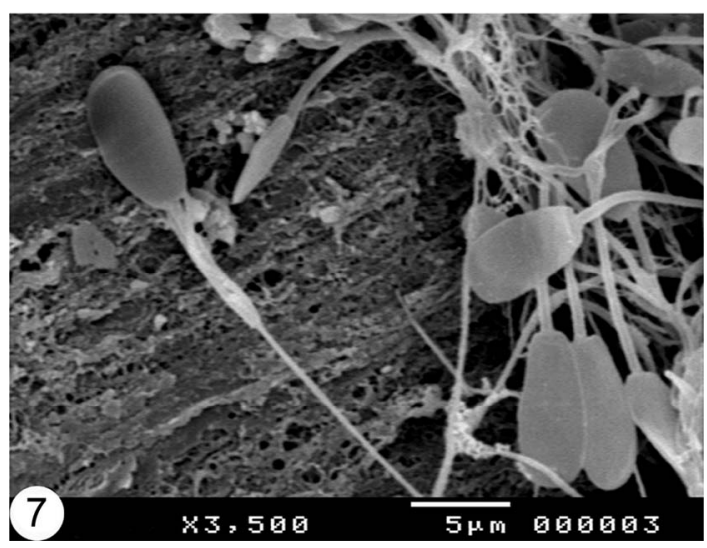

Figure 7. Scanning electron micrographs showing epididymal sperms in camel. Notice that the sperms are healthy and large.

segment is further subdivided into proximal, intermediate and distal parts. The epididymal duct is lined by a pseudostratified ciliated columnar epithelium and surrounded 
by thin lamina propria and circular smooth muscular layer (muscular coat). The height of the epithelium varies between the different segments of the epididymial duct, the highest epithelium is seen in the initial segment and decreases gradually toward the terminal segment. The epithelium consists of five cell populations: principal, basal, apical dark and halo cells. The distribution of these cells varies in different epididymal segments. However, principal and basal cells are the most frequent cell types throughout the whole length of the epididymal duct (Figures 8-12).

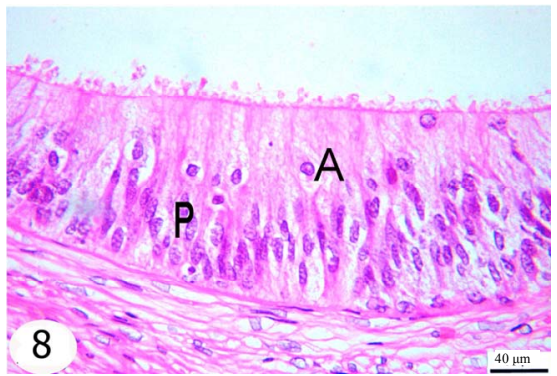

Figure 8. Paraffin sections stained with H\&E showing the distribution of cells within the epithelial lining of the epididymal segments. Notice the presence of principal $(\mathrm{P})$ and apical cells (A).

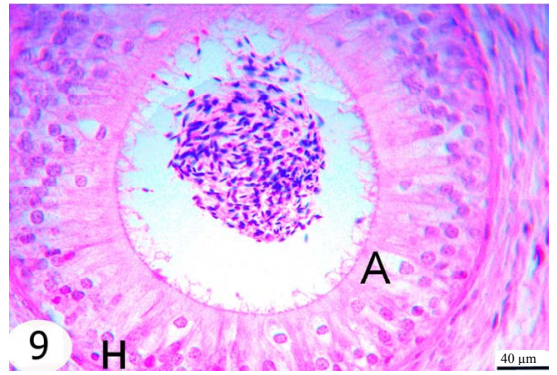

Figure 9. Paraffin sections stained with H\&E showing the distribution of cells within the epithelial lining of the epididymal segments. Notice the presence of halo cells $(\mathrm{H})$, and apical cells (A).

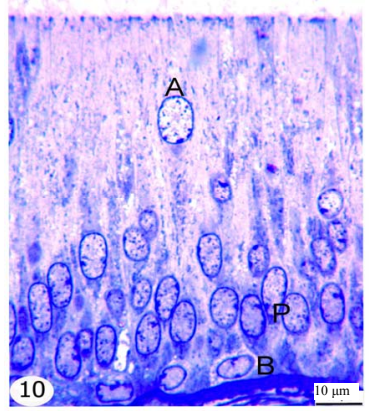

Figure 10. Semithin sections stained with toluidine blue showing the epithelial lining of the initial segment. The epididymal epithelium is ciliated pseudostratified columnar formed of principal cells (P), basal cells (B), apical cells (A) and dark cells.

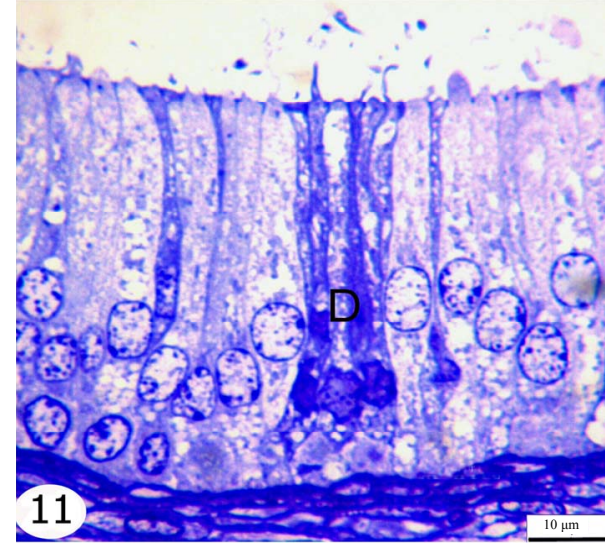

Figure 11. Semithin sections stained with toluidine blue showing the epithelial lining of the middle segment. The epididymal epithelium is ciliated pseudostratified columnar formed of principal cells, basal cells, apical cells, and dark cells (D).

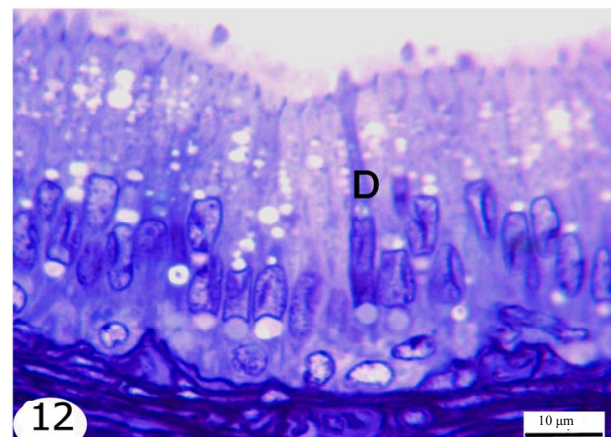

Figure 12. Semithin sections stained with toluidine blue showing the epithelial lining of the terminal segment. The epididymal epithelium is ciliated pseudostratified columnar formed of principal cells, basal cells, apical cells, dark cells (D). The highest epithelium is seen in the initial segment and decrease gradually toward the terminal segment.

\subsubsection{The Principal Cells}

The principal cells are long cylindrical, columnar cells extending from the basement membrane to the lumen. The nuclei of the principal cells are vesicular with evident one or two nucleoli. In the initial segment, these nuclei are oval, elongated in shape and basally located (Figure 10), but in the middle segment, they are rounded and positioned at higher levels but not at one line (Figure 11). In the terminal segment, the nuclei are small, darkly stained and densely arranged; they seem to form one row just above the level of the basal cells (Figure 12). The cytoplasm of the principal cells is abundant and has variably sized vacuoles which are mostly seen in the distal part of the middle and the terminal segments (Figures $8,11,12$ ).

\subsubsection{The Basal Cells}

The basal cells are small oval to spherical cells with 
spherical, vesicular nuclei and lightly stained cytoplasm. They are located between the principal cells resting on the basement membrane. These cells are seen along the whole length of the epididymal duct but they increase gradually in number toward the terminal segment (Figures 10-12).

\subsubsection{The Apical Cells}

The apical cells are wedge or triangular in shape, with the apex facing basally and the base facing apically, they have rounded apically situated nuclei. These cells are located between the principal cells being more frequent in the initial segment, proximal and intermediate parts of the middle segment then decrease gradually in number toward the distal part of the middle segment until being very few or nearly absent in the terminal segment (Figures 8-12).

\subsubsection{The Dark Cells}

The dark cells are narrow, tall and darkly stained cells extending from the basement membrane to the lumen between the principal cells. They have dark, elongated fusiform nuclei. They are observed in all epididymal segments but they increase in frequency toward the terminal segment (Figures 10-12).

\subsubsection{The Halo Cells}

The hallo cells are rounded or irregular in shape with dark, small nuclei surrounded by a light halo of pale cytoplasm. They are observed throughout the epididymal duct variably distant from the basal lamina, but they mostly occupy a higher position in the initial segment (Figure 9).

Strongly PAS-positive granules may be demonstrated in the basal portion of the epithelium practically in principal cells (Figure 13). The luminal surface of the epididymal epithelium is covered by stereocilia which are long in the initial segment and decrease gradually until being very short in the terminal segment where they resemble a brush border. These stereocilia exhibit weak to moderate PAS and Alcian blue positive reaction (Figures 13 and 14). The epithelium contains intraepithelial glands which are filled with intensely PAS-positive material and surrounded by simple columnar or cuboidal cells. These glands are observed mainly in the distal part of the middle segment, but may be occasionally seen in other parts (Figures 15 and 16). The above mentioned glands are demonstrated also in different stages of their formation which start as small spaces within the epithelium. These spaces coalesce to form larger ones which become surrounded by the neighboring cells. When these glands attain a larger size, the surrounding cells facing the basement membrane become cuboidal, while those facing the lumen of the epididymal duct attain a flat shape. In later stages, these glands

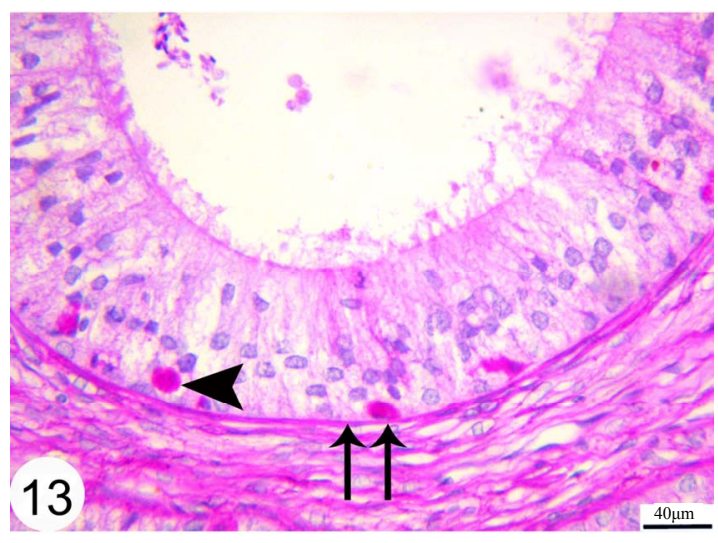

Figure 13. Paraffin sections of the middle segment of the epididymal duct stained with PAS showing PAS positive granules in the basal part of the epithelium (arrow head). The basement membrane (double arrow).

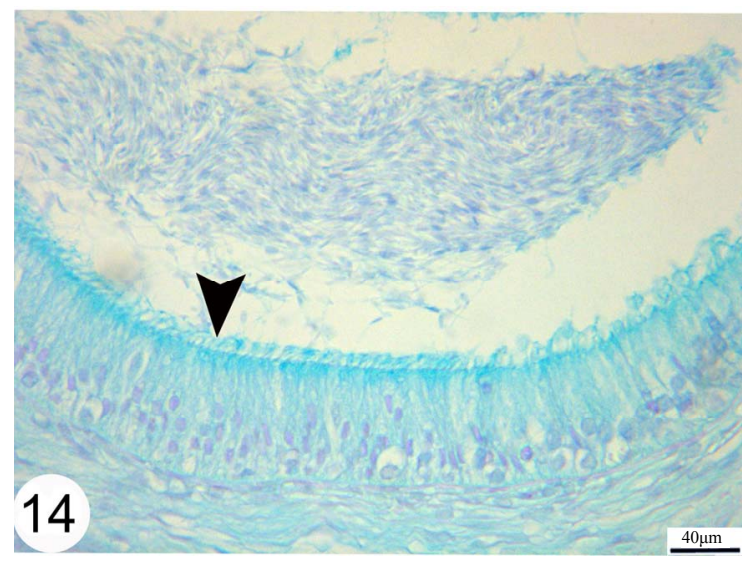

Figure 14. Paraffin sections of the middle segments stained with Alcian blue showing moderate positive staining of the cilia (arrow head).

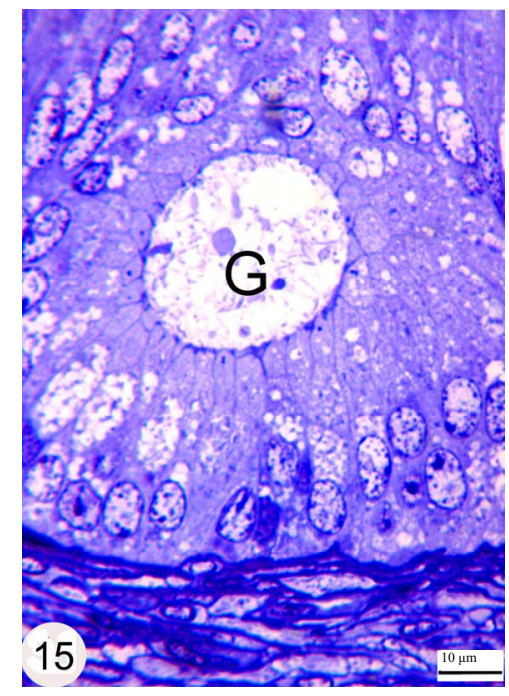

Figure 15. Semithin sections stained with toluidine blue showing the intraepithelial gland (G) within the distal part of the middle segment. 


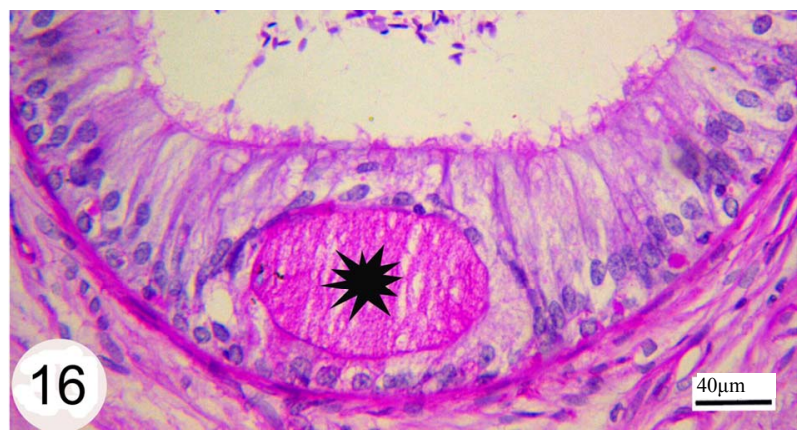

Figure 16. Paraffin section stained with PAS showing strong PAS positive material filling the lumen of the intraepithelial gland (asterisk).

open into the lumen of the epididymal duct (Figure 17). The epithelium is surrounded by a thin lamina propria which is formed of fine collagen in addition to elastic fibers in a continuous layer. The latter exhibits a strong positive reaction to the Weigert's resorcin fuchsin stain. The thickness of this layer of elastic fibers increases toward the terminal segment (Figures 18 and 19). The lamina propria is surrounded by numerous layers of circularly and obliquely arranged smooth muscle fibers which form a thick muscular coat in the initial segment, slightly thin in the middle segment but it is very thick in the terminal segment. In the terminal segment, the obliquely arranged smooth muscle fibers increase in proportion and tend to be longitudinally oriented. The interstitium consist of loose connective tissue with many cells, fibers and vessels (Figures 20 and 21).

\section{Discussion}

The epididymis constitutes an important part of the male genital duct system. It plays key role in the maturation and storage of spermatozoa [17].

Anatomically and in agreement with previous studies $[7,18]$ the epididymis of camel consists of three parts i.e. head, body and tail. The whole organ is covered by a thick tunica albuginea which do not allow the epididymal duct to be visualized grossly through it. Another reason for the latter statement could be attributed to the narrow epididymal duct as compared to some other domestic animals like bovines [19] where the epididymal duct is about one third wider than that observed in camel in the present work.

Recently the classic classification of the epididymis into head, body and tail has been found to be unsatisfactory [20]. The new classification depends on histological or histochemical and ultrastructural characteristics of the epithelial lining the epididymal duct. Based on this, the epididymis may be subdivided into several segments, whose distribution and number are characteristic for each species $[21,22]$. In camel and in consistence with $[7,18]$,

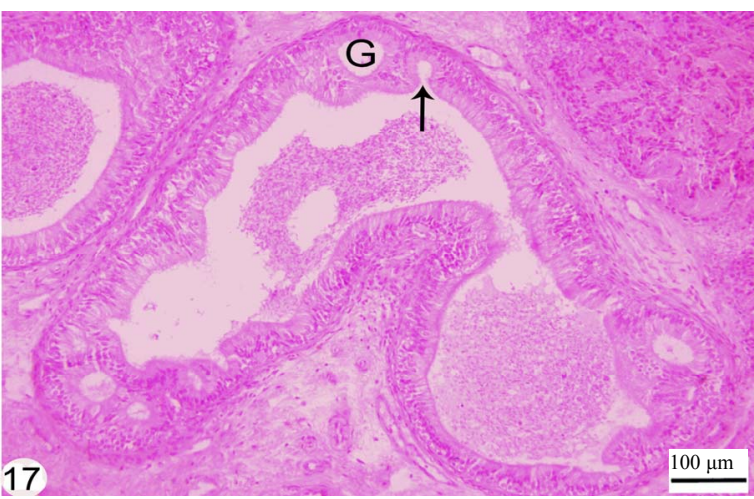

Figure 17. Paraffin section stained with H\&E showing the different stages of formation of the intraepithelial gland (G) that in latter stages opens into the lumen (arrow).

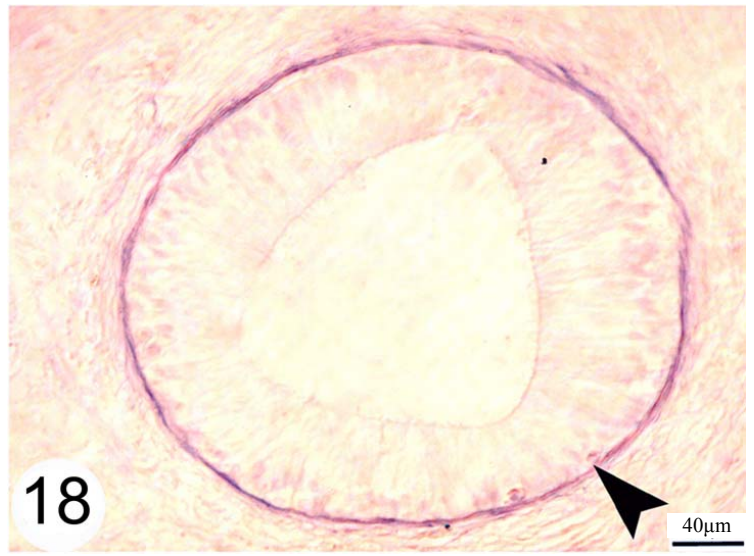

Figure 18. paraffin sections of the initial segment stained with Weigert's resorcin fuchsin shows a continuous layer of elastic fibers surrounding the basement membrane of the epididymal duct (arrow head).

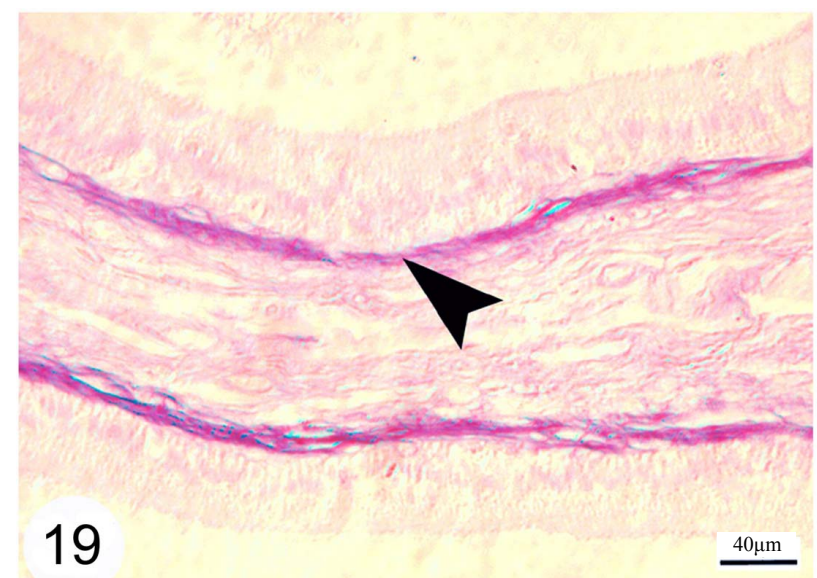

Notice that this layer of elastic fibers is thicker in the terminal segment as compared with other segments.

Figure 19. Paraffin sections of the terminal segment stained with Weigert's resorcin fuchsin shows a continuous layer of elastic fibers surrounding the basement membrane of the epididymal duct (arrow head). 


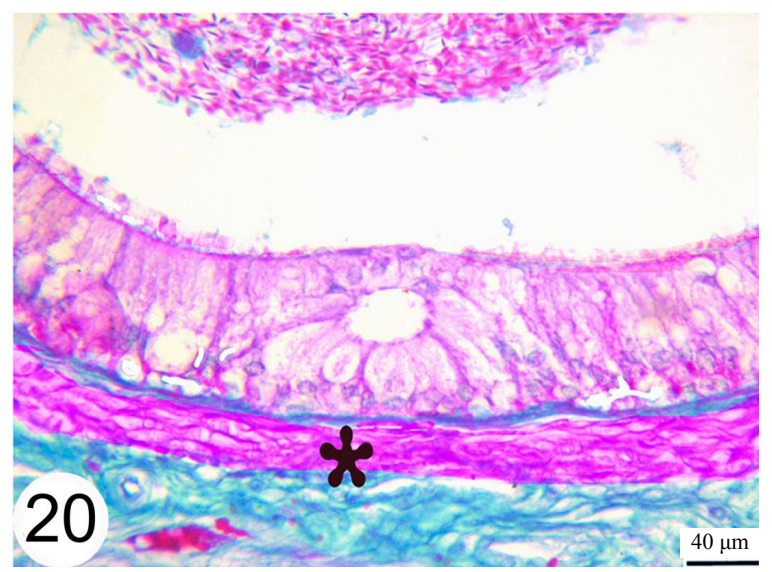

Figure 20. Paraffin sections of the distal part of the middle segment stained with Crossmon's Trichrome shows the surrounding muscular layer (asterisk).

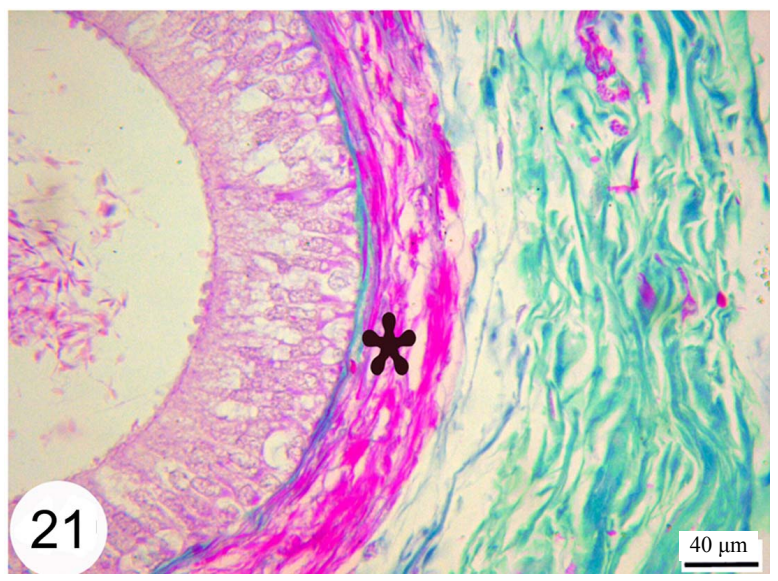

Figure 21. Paraffin sections of the distal part of the terminal segment stained with Crossmon's Trichrome shows the surrounding muscular layer (asterisk) which increase in thickness toward the terminal segment.

the epididymis is subdivided into initial, middle and terminal segments, of which the middle segment is further subdivided into proximal, intermediate and distal parts. The histological and histochemical characteristics of different epididymal segments include regional variations in the total diameter, epithelial height, morphology and distribution of different cells, length of stereocilia, and thickness of the elastic fibers in the lamina propria as well as thickness of the muscular coat. [7] have mentioned that, the initial segment possesses high epithelium with long stereocilia, the middle segment is characterized by the cytoplasmic vacuoles and mass collections of spermatozoa in the lumen, whereas in the terminal segment the epithelium is low, the lumen is very wide and packed with spermatozoa. Our observations are partly different from those of [7] where the vacuoles, seen in the principal cells are found mainly in both middle and terminal segments.
The current study supports the previous findings in different species including camel concerning the gradual decrease in the epithelial height of the epididymal duct from the initial through middle to the terminal segments [7,18,19,23-26]. This gradual decrease in the epithelial height distalwards the epididymal duct may mechanically facilities passage of the sperms toward the terminal segment. High epithelium in the initial segment may, however indicate a more absorptive power of the epithelium in this segment. In this respect, [27] reported that in bull, over $90 \%$ of the fluids entering the epididymal duct is absorbed in the head of the epididymis. In addition [28] mentioned that, the removal of fluid is associated with a net resorption of sodium ions between the rete testis and the proximal part of the epididymis in rat. Moreover and in agreement with previous reports [21,26,29-31] the epididymal epithelium in the initial segment is supported by a complex set of long and branched stereocilia that decrease in length through the middle segment being very short forming brush border in the terminal segment. Well-developed cilia in the initial segment increase the surface area facilitating the movement of molecules into and out of the cell $[31,32]$. The decrease in the height of stereocilia between the head and the tail of the epididymis could be attributed to the more active absorptive and secretory functions of the head of the epididymis as compared with those of the tail of the epididymis [33]. Unlike the findings of [19] who mentioned that, the stereocilia show distinct stains with Alcian blue, the stereocilia of the camel epididymis in the current study stain positive with PAS and Alcian blue. In this respect [34] have ascribed this staining pattern in equine head of the epididymis to carboxyl group of glycoproteins and/or glycolipids associated sialic acids or sulfate polysaccharides in the stereocilia.

The epithelial lining the epididymal duct is ciliated pseudostratified columnar comprising mainly five cell types, namely principal, basal, apical, dark and halo cells. These findings simulate previous observations in the camel $[18,35]$. Among the above mentioned cells, the basal cells are characterized by high nuclear: cytoplasmic ratio [19] and they have been suggested to be a stem cell of the epididymal epithelium [36]. They may also have roles in immune defense, phagocytosis and production of antioxidant [37].

In agreement with [19,23-25], the principal cells are the major cell types of the epididymal epithelium. The nuclei of these cells in the initial segment are elongated oval in shape and basally located, but in the middle segment they are rounded and found at higher levels but not at one line. In the terminal segment the nuclei are small, darkly stained and densely arranged; they seem to form one row just above the level of basal cells. The latter observation could be due to enormous widening of the 
epididymal duct in this segment. Unlike observations of [35] who mentioned that, the dark cells are rare cells, these cells are observed in all epididymal segments in the current study but they increase in frequency toward the terminal segment. Different hypotheses have been suggested to the origin and physiological role of the dark cells. [38] as well as [39] have considered it a modification of a single cell type at different phases of its metabolic cycle. [40-44] believed that, these cells are holocrine secretory cells as they lack stereocilia and have large clear vacuoles with finely granulated material. However $[45,46]$ suggested that, they are dying principal cells, a suggestion which seem to be the most plausible for the camel epididymis. The latter opinion is supported by the fact that, the variations of cytoplasmic density could be interpreted as intermediate stage prior to death [35]. Our observations support the latter statement where we observed the dark cells in different staining intensities, sometimes without any cytoplasmic details.

Light microscopically, the apical cells of the camel epididymis share many characteristics of adjacent principal cells concerning their nuclear and cytoplasmic pictures. These results are consistent with those of [35] in the same species. In other species, the apical cells show more differences from principal cells. [47] have mentioned that, apical cells of rat contain fewer organelles, whereas [45,48] in monkey as well as [19] in bovines ascertained that, these cells contain strikingly large number of mitochondria and have designated them as mitochondrion-rich cells. [35] has observed that, the structure of the apical cells of the camel is relatively simple with a moderate mitochondrial content but, like other species, the Golgi complex is small. In our opinion, the apical cells observed in camel in the present study could be actually principal cells mechanically insinuated between the apical portions of other principal cells. This postulation agrees with the statement of [49] that, the only difference between apical and principal cells is the position of their nuclei and they have assumed that, they perform the same functions. The latter authors have found connections between the apical cells of the mouse and the basement membrane.

In agreement with [50] the epididymal epithelium of the camel in the present study demonstrates numerous intraepithelial glands in the middle segment. However in the present study these glands are sometimes also observed in the initial and terminal segments. [51] have described similar gland in the initial epididymal segments of the bull. These intraepithelial glands have been also described in different species and given different names. They are designated as intraepithelial vesicles in man [52] intraepithelial vacuolar structure in camel [7]; intraepithelial crypts in equine [53] and in bull [19] and intraepithelial cysts in cat [26]. In the present work, the above mentioned glands start as a collection of small spaces within the basal part of the epididymal epithelium which coalesce to form a large space encircled by the surrounding cells. By time these spaces grow up and the surrounding cells facing the lumen attain flat form and later on open into the lumen. In the same respect, [51] have mentioned that, these structures are formed by vacuolation of one or more epithelial cells which increase in size and later on degenerate. They suggested that, the formation of intraepithelial vesicles (glands) is an abnormal process which distorts the lining of the epididymal duct but probably has a little effect upon the normal function because they rarely occur in sufficient extent to obliterate the normal epithelium. Unlikely, in the present study, these glands are never seen distorting the line of the duct. We assume that, these glands are formed when secretions are accumulated in a basal position below the nuclei of the principal cells and fail to access the lumen. This explanation is supported by the above mentioned morphogenesis of these structure and also their PAS positive contents as revealed in the present study. The last assumption is supported by [54] that, the intraepithelial crypts constitute a secretory microenvironment. In addition, [19] have mentioned that, the luminal surface of these glands express strong immunoreactivity for two types of protein fractions (S-100 and $\mathrm{ACE})$. Both protein fractions have a well-known role in regulation of the fluid and electrolyte transepithelial transport [55-58].

The lamina propria of the epididymal duct, as demonstrated in the present study, contains a layer of interlacing elastic fibers which becomes thicker toward the terminal epididymal segment. These elastic fibers may allow adequate elasticity of the duct that could help in its expansion. Moreover, the lamina propria is surrounded by numerous layers of circularly and obliquely arranged smooth muscle fibers which always increase in thickness toward the terminal segment. This comes in agreement with previous studies in different species including camel [18,23-25]. These authors have also added that, the periductular smooth muscle along the length of the epididymal duct may play an important role in the passage of the sperms toward the terminal segment. [30] have mentioned that, the head and body of the epididymis demonstrate spontaneous rhythmic peristaltic contractions that serve to convey the sperms along the duct. Fewer such contractions are observed in the tail region. The thick muscular coat in the terminal segment where some of them are arranged longitudinally may help in the process of ejaculation [19].

PAS positive granules are demonstrated in different segments of the epididymal duct. The intraepithelial glands are full of PAS positive material. The PAS positivity gives evidence for the presence of glycoprotein in 
relation to a secretory product [49], which could be an indication of increased activity [26].

\section{REFERENCES}

[1] C. Novoa, "Reproduction in Camelidae," Journal of Reproduction and Fertility, Vol. 22, No. 1, 1970, pp. 3-20.

[2] H. Schwartz and M. Dioli, "The One Humped Camel (Camelus dromedarius) in Eastern Africa," 1st Edition, Verlag Josef Margraf, Munich, 1992.

[3] B. Brown, "A Review on Reproduction in South American Camelids," Animal Reproduction Science Journal, Vol. 58, No. 3-4, 2000, pp. 169-195. doi:10.1016/S0378-4320(99)00081-0

[4] A. Osman and E. El Azab, "Gonadal and Epididymal Sperm Reserves in the Camel, Camelus dromedarius," Journal of Reproduction and Fertility, Vol. 38, 1974, pp. 452-430. doi:10.1530/jrf.0.0380425

[5] P. Senger, "The Organization and Functionof the Male Reproductive Tract," In: P. L. Senger, Pathways to Pregnancy and Parturition, 2nd Edition, Cadmus Professional Communications Science Press Division, Ephrata, 2006.

[6] R. Nickel, A. Schummer and E. Seiferle, "The Viscera of the Domestic Mammals," 2nd Edition, Verlag Paul Parey Berlin, Hamburg, 1979.

[7] M. Tingari and K. Moniem, "On the Regional Histology and Histochemistry of the Epididymis of the Camel (Camelus dromedarius)," The Journal of the Society for Reproduction and Fertility, Vol. 57, No. 1, 1979, pp. 1120. doi:10.1530/jrf.0.0570011

[8] B. Romeis, "Mikroskopische Technik," Urban und Schwarzenberg, 17. Auflage, München, Wien, Baltimore, 1989.

[9] H. Harris, "On the Rapid Conversion of Haematoxylin into Haematein in Staining Reactions," Journal of Applied Microscopic Laboratory Methods, Vol. 3, No. 3, 1900, p. 777.

[10] J. Mc Manus, "Histological Demonstration of Mucin after Periodic Acid," Nature (London), Vol. 158, No. 4006, 1946, pp. 158-202.

[11] H. Steedman, "Alcian Blue 8GS: A New Stain for Mucin," The Quarterly Journal of Microscopical Science, Vol. 91, No. 16, 1950, pp. 477-479.

[12] G. Crossmon, “A Modification of Mallory's Connective Tissue Stain with a Discussion of Principles Involved," The Anatomical Record, Vol. 69, No. 1, 1937, pp. 33-38. doi:10.1002/ar.1090690105

[13] C. Weigert, "Übereine Methodezur Färbungelastischer Fasern," ZentrablattfüerAllgemeinePathologie und Pathologische Anatomie, No. 9, 1898, pp. 289-292.

[14] A. Karnovsky, "A Formaldehyde-Glutaraldehyd Fixative of High Osmolarity for Use in Electron Microscopy," The Journal of Cell Biology, Vol. 27, 1965, pp. 137-138.

[15] H. Mollenhauer, "Plastic Embedding Mixture for Use in Electron Microscopy," Stain Technology, Vol. 39, 1964, pp. 111-114.

[16] K. Richardson, L. Jarett and E. Finke, "Embedding in Epoxy Resins for Ultrathin Sectioning in Electron Microscopy," Stain Technology, Vol. 35, 1960, pp. 313-323.
[17] J. Bedford, "Effect of Duct Ligation on the Fertilizing Ability of Spermatozoa in the Epididymis of the Rabbit," Journal of Experimental Zoology, Vol. 166, No. 2, 1967, pp. 271-282. doi:10.1002/jez.1401660210

[18] S. Ebada, "Light and Electron Microscopic Studies on the Epididymis of the Dromedary Camel," M.V.Sc. Thesis, Faculty of Veterinary Medicine, Zagazig University, Zagazig, 1994.

[19] M. Alkafafy, "Glycohistochemical, Immunohistochemical and Ultrastructural Studies of the Bovine Epididymis," Ph.D. Thesis, Anatomy Faculty of Veterinary Medicine, Ludwig-Maximilians-Universität, Muenchen, 2005.

[20] T. Glover and L. Nicander, "Some Aspects of Structure and Function in the Mammalian Epididymis," Journal of Reproduction and Fertility, Vol. 13, Suppl. 13, 1971, pp. 39-50.

[21] H. Dellmann and K. Wrobel, "Male Reproductive System," In: H. D Dellmann and E. M. Brown, Eds., Textbook of Veterinary Histology, 2nd Edition, Lea \& Fiebiger, Philadelphia, 1981.

[22] K. Wrobel, "Male Reproductive System," In: H. D. Dellmann and J. Eurell, Eds., Textbook of Veterinary Histology, Chapter 12, 5th Edition, Williams and Wilkins, Philadelphia, 1998.

[23] G. Erkmann, "Histologische und Histochemischeuntersuchungenzursegmenteinteilung des Nebenhodensvom Rind vor und Nachgeschlechtsreif," Cytobiologie, Vol. 3, No. 1, 1971, pp. 37-69.

[24] F. Sinowatz, "Ultrastrukturelle und Enzymehistochemischentersuchungen am Ductusepididymidis des Rindes," Fortschritte der veterinärmedizin, Verlage Paul Berlin Hamburg, 1981.

[25] H. Goyal, "Morphology of the Bovine Epididymis," American Journal of Anatomy, Vol. 172, No. 2, 1985, pp. 155-172. doi:10.1002/aja.1001720205

[26] E. Axner, M. Malmqvist, C. Linde-Forsberg and H. Rodriguez-Martinez, "Regional Histology of the Ductus Epididymis in the Domestic Cat," Journal of Reproduction and Development, Vol. 45, No. 2, 1999, pp. 151-160.

[27] B. Crabo, "Studies on the Composition of Epididymal Content in Bulls and Boars," Acta Veterinaria Scandinavica, Vol. 6, Suppl. 5, 1965, pp. 1-94.

[28] T. Turner, "Resorption versus Secretion in the Rat Epididymis," Journal of Reproduction and Fertility, Vol. 72, No. 2, 1984, pp. 509-514. doi:10.1530/jrf.0.0720509

[29] L. Johnson, R. Amann and D. Pickett, "Scanning Electron Microscopy of the Epithelium and Spermatozoa in the Equine Excurrent Duct System," American Journal of Veterinary Research, Vol. 39, No. 9, 1978, pp. 14281434.

[30] M. Ross, E. Reith and L. Romrell, "Histology. A Text and Atlas," 2nd Edition, Williams \& Wilkins, Philadelphia, 1989.

[31] L. Junqueira and J. Carneiro, "Basic Histology: Text and Atlas," 10th Edition, McGraw Hill, Toronto, New York, London, Sydney, Melan, Newdelhy, Lisbon, Madrid, 2003.

[32] F. Martini, W. Ober, C. Garrison, K. Welch and R. 
Hutchings, "Fundamentals of Anatomy \& Physiology," 5th Edition, Prentice Hall, Upper Saddle River, 2001.

[33] M. Yamamoto and T. Turner, "Epididymis, Sperm Maturation, and Capacitation," In: Infertility in Male, 2nd Edition 191, Chapter 6, Mosby Year Book, St. Louis, Baltimore, Boston, Chicago, London, Philadelphia, Sydney, Toronto.

[34] M. Lòpez, P. Grez, I. Gribbel and E. Bustos-Obregon, "Cytochemical and Ultrastructural Characteristics of the Stallion Epididymis (EquusCaballus)," Journal of Submicroscopic Cytology, Vol, 21, No. 1, 1989, pp. 103-120.

[35] M. Tingari, "The Fine Structure of the Epithelial Lining of the Epididymis of the Camel (Camelus dromedarius) with Special Reference to Regional Differences," Journal of Anatomy, Vol. 165, 1989, pp. 201-214.

[36] D. Samuelson, "Textbook of Veterinary Histology," Saunders an Imprint of EL-Sevier, Amsterdam, 2007.

[37] L. Franca, G. Avelar and F. Almeida, "Spermatogenesis and Sperm Transit through the Epididymis in Mammals with Emphasis on Pigs," Theriogenology, Vol. 63, No. 2, 2005, pp. 300-318. doi:10.1016/j.theriogenology.2004.09.014

[38] A. Ladman and W. Young, "An Electron Microscopic Study of the Ductuliefferentes and Rete Testis of the Guinea Pig," Journal of Biophysical and Biochemical Cytology, Vol. 4, No. 2, 1958, pp. 219-226. doi:10.1083/jcb.4.2.219

[39] M. Tingari, "The Fine Structure of the Epithelial Lining of the Excurrent Duct System of the Testis of the Domestic Fowl (Gallus Domesticus)," Quarterly Journal of Experimental Physiology, Vol. 57, No. 3, 1972, pp. 271295.

[40] J. Martan and P. Risley, "The Epididymis of Mated and Unmated Rats," Journal of Morphology, Vol. 113, No. 1, 1963, pp. 1-15.

[41] J. Martan and P. Risley, "Holocrine Secretory Cells of the Rat Epididymis," The Anatomical Record, Vol. 146, No. 2, 1963, pp. 173-189. doi:10.1002/ar.1091460211

[42] J. Martan and J. Allen, "Morphological and Cytochemical Properties of the Holocrine Cells in the Epididymis of the Mouse," Journal of Histochemistry \& Cytochemistry, Vol. 12, No. 8, 1964, pp. 628-639. doi:10.1177/12.8.628

[43] J. Martan, P. Risley and Z. Hruban, "Holocrine Secretary Cells of the Human Epididymis," Fertility Academy of Sciences, No. 55, 1964, pp. 585-593.

[44] P. Risley and C. Skrepetos, "Histochemical Distribution of Cholinesterases in the Testis Epididymis and Vas Deferens of the Rat," The Anatomical Record, Vol. 148, No. 2, 1964, pp. 231-249. doi:10.1002/ar.1091480213

[45] A. Hoffer, "The Ultrastructure of the Ductus Deferens in Man, "Biology of Reproduction, Vol. 14, No. 4, 1976, pp. 425-443. doi:10.1095/biolreprod14.4.425

[46] R. Paniagua, J. Regadera, M. Nistal and M. Abaurrea, "Histological, Histochemical and Ultrastructural Variations along the Length of the Human Vas Deferens before and after Puberty," Acta Anatomica, Vol. 111, No. 3,
1981, pp. 190-203. doi:10.1159/000145467

[47] D. Hamilton, "Structure and Function of the Epithelium Lining the Ductuliefferents, Ductus Epididymis and Ductus Deferens in the Rät," In: D. W. Hamilton and R. O. Greep, Eds., Handbook of Physiology, Vol. 5, Male Reproductive System, American Physiology Society, Washington DC, 1975.

[48] A. Ramos and M. Dym, "Fine Structure of the Monkey Epididymis," American Journal of Anatomy, Vol. 149, No. 4, 1977, pp. 501-532. doi:10.1002/aja.1001490407

[49] A. AbouHäila and M. Fain-maurel, "Regional Differences of the Proximal Part of Mouse Epididymis: Morphological and Histochemical Characterization," The Anatomical Record, Vol. 209, No. 2, 1984, pp. 197-208. doi:10.1002/ar.1092090207

[50] U. Singh and M. Bharadwaj, "Histological Studies on the Testicular Seminal Pathway and Changes in the Epididymis of the Camel (Camelus dromedarius)," Acta Anatomica, No. 108 , 1980, pp. 481-489. doi:10.1159/000145347

[51] L. Nicander, "Studies on the Regional Histology and Cytochemistry of the Ductusepididymidis in Stallions, Rams and Bulls," Acta MorphologicaNeerlando-Scandinavica, Vol. 1, No. 4, 1958, pp. 337-362.

[52] R. Hodges and H. Hanley, "Malformations of the Epithelium of the Ductus Epididymis," Journal of Reproduction and Fertility, Vol. 20, No. 1, 1969, pp. 45-50.

[53] S. Arrighi, M. Romanello and C. Domeneghini, "Ultra Structure of Epididymal Epithelium in EquusCaballus," Annals of Anatomy, Vol. 175, No. 1, 1993, pp. 1-9. doi:10.1016/S0940-9602(11)80229-3

[54] S. Arrighi, M. Romanello and C. Domeneghini, "Ultrastructural Study on the Epithelium Lining Ductus Epididymis in Adult Cats (Feliscatus)," Archives Italiennes de Biologie, No. 97, 1986, pp. 7-24.

[55] S. Molin, L. Rosengren, J. Baudier, A. Hamberger and K. Haglid, "S-100 Alpha-Like Immunoreactivity in Tubules of Rat Kidney. A Clue to the Function Ofa 'Brain-Specific' Protein," Journal of Histochemistry \& Cytochemistry, Vol. 33, No. 4, 1985, pp. 367-374. doi:10.1177/33.4.3884707

[56] Y. Zhou, Z. Sun, A. Means, P. Sassone-Corsi and K. Bernstein, "CAMP-Response Element Modulator Tau Is a Positive Regulator of Testis Angiotensin Converting Enzyme Trans-Cripttion," Proceedings of the National Academy of Sciences of the United States of America, Vol. 93, No. 22, 1996, pp. 12262-12266. doi:10.1073/pnas.93.22.12262

[57] P. Leung, T. Wong and C. Sernia, "Angiotensinogen Expression by Rat Epididymis: Evidence for an Intrinsic, Angiotensin-Generating System," Molecular and Cellular Endocrinology Journal, Vol. 155, No. 1-2, 1999, pp. 115122.

[58] O. O’ Mahony, O, Djahanbahkch, T. Mahmood, J. Puddefoot and G. Vinson, "Angiotensin II in Human Seminal Fluid," Human Reproduction, Vol. 15, No. 6, 2000, pp. 1345-1349. 